J. Dairy Sci. 96:725-725

http://dx.doi.org/10.3168/jds.2013-96-1-725

(C) American Dairy Science Association ${ }^{\circledR}, 2013$.

\title{
Erratum to "Low-protein solid feed improves the utilization of milk replacer for protein gain in veal calves" (J. Dairy Sci. 95:6654-6664)
}

\author{
H. Berends, J. J. G. C. van den Borne, S. J. J. Alferink, C. G. van Reenen, E. A. M. Bokkers, \\ and W. J. J. Gerrits
}

The discussion (page 6662) and conclusions (page 6663) contained incorrect data for the effect of SF intake on gross efficiency of nitrogen retention. At 108 $\mathrm{kg}$ of BW, the gross efficiency of $\mathrm{N}$ retention was $61 \%$ for calves without SF, and it increased with $\mathrm{SF}$ intake by $6.7 \% / \mathrm{kg}$ of DM of SF per day. At $164 \mathrm{~kg}$ of BW, this efficiency was $49 \%$ for calves without SF, and it increased by $12.3 \% / \mathrm{kg}$ of $\mathrm{DM}$ of SF per day.

The authors regret the error.

\section{REFERENCES}

Berends, H., J. J. G. C. van den Borne, S. J. J. Alferink, C. G. van Reenen, E. A. M. Bokkers, and W. J. J. Gerrits. 2012. Low-protein solid feed improves the utilization of milk replacer for protein gain in veal calves. J. Dairy Sci. 95(11):6654-6664. 